\title{
EFFECTS OF TWEEN 80 ON PROTEASE PRODUCTION BY Candida lipolytica
}

\section{(Efectos del Tween 80 en la producción de proteasa por Candida lipolytica)}

\author{
Aline E. Nascimento '; Allana E. Nascimento ${ }^{1}$; \\ G. M. Campos Takaki ${ }^{1,2}$ \\ Laboratório de Imunopatologia Keizo Asami ${ }^{1}$, \\ Departamento de Antibióticos ${ }^{2}$ - Universidade Federal de Pernambuco \\ Campus Universitário. 50.64()-901 Recife - PE, Brasil
}

Palabras clave: Candida lipolytica, proteasa, crecimiento, Tween 80.

Key Words: Candida lipolytica; protease; growth; Tween 80

\section{SUMMARY}

The influence of Tween 80 , anon ionic tensoactive agent on extracellular protease produced by Candida lipolytica was investigated. The microorganism was grown in a medium containing different surfactant concentrations added to culture at different intervals of growth. The addition of the surfactant on the C. lipolytica culture medium, resulted in a increase of intracellular and extacellular protease activity as well as in an increase in the growth of the fingi which could be related to Tween 80 concentration and addition time.

\section{INTRODUCTION}

Candida lipolytica is known as a lipase-producing and hydrocarbon-assimilating yeast. Several investigators have reported that isolates of $C$. lipolytica are proteolytic but the exicnt and magnitude of proteolysis among strains of the specie have not been documented and preliminar data suggest that this protcolytic activity is inducible or repressed in the presence of glucose (Ahear et al., 1968; Tobe et al., 1976: Meycrs \& Ahearn, 1977; Ogrydziak et al.,1977; Yamada \& Ogrydziak, 1983 Lodder \& Krieger van Rij: 1984 ).

Recently, interest in the pathogenesis of Candida infection has led to studies on cxtracellular protcases produced by some species of the genus, which are positive for protease activity. The protease activity is related to invasive properties and virulence of the Candida genus (Chakrabarti ct al..1991).

\section{RESUMEN}

Se estudió la acción del Tween 80, agente tensoactivo no iónico, sobre la proteasa producida por Candida lipolytica. El microorganismo fire cultivado en medio de cultivo conteniendo diferentes concentraciones del agente, el cual fue introducido en el medio en diferentes intervalos de tiempo. La presencia del agente en el medio de cultivo incrementó la actividad de la proteasa extracelular e intracelular y el crecimiento del hongo. Los efectos del agente podrian estar relacionados con el tiempo de adición y las concentraciones empleadas en el medio de cultivo.

A group of suface-active agents, the Tweens (fatty acid esters of polyoxyethylene sorbitan) is currently being used to solubilize membrane proteins (Helenius \& Simons, 1975; Tanford \& Reynolds, 1974) and to promote cellular growth and enzyme productions.when included in culture media of several microorganisms supplying saturated and unsaturated fatty acids to organisms (Reese \& Maguire, 1969; Jagger et al., 1985; Asther \& Corrieu, 1987: Espinosa et al., 1990; Okcke \& Okolo, 1990).

The present studies were undertaken to investigate in vitro of Tween 8() can influence the extracellular and intracellular protease production by Candida lipolytica.

\section{MATERIALS AND METHODS}

\section{Organism and Cultural Conditions}

Caindida lipolytica IA 1055 was grown in Yeast Mold medium described by Cirigliano \& Carman (1983),

Corresponding Author: Dr. G.M. Campos-Takaki CEP: 50670-901 FAX: (081) 2718485; E.mail: gmct@npdl.ufpe.br 
over $96 \mathrm{~h}$ at $27^{\circ} \mathrm{C}$ on a reciprocal shaker $(120 \mathrm{~Hz})$. The surfactant, Tween 80 (Sigma, St. Louis, Mo), in concentrations of $0,01 \%, 0,05 \%, 0,2 \%, 0,5 \%$ and $1 \%$ was added to the medium at intervals of $0,8,16$ and $24 \mathrm{~h}$ during culture. These intervals corresponded to beginning of culture, beginning of exponential growth phase, intermediate growth phase, and end of exponential phase/ begining os stationary growth phase, respectively.

\section{Growth Estimation}

The cellular growth was determined by viable cell counts which were measured after a serial dilution in $\mathrm{pH}$ 7,0 PBS buffer of culture samples collected at intervals of $0,8,16,24,48,72,96 \mathrm{~h}$ by plating on Yeast Mold Agar (YMA)medium (Cirigliano \& Carman,1983). The plate were prepared in triplicate and were incubated for $24 \mathrm{~h}$ at $27^{\circ} \mathrm{C}$.

\section{Enzyme Assay}

The proteaseactivity of Candida lipolytica was determined by the method of Hankin \& Anagnostakis (1975) modified by using YMA medium. The protease activity was tested by two methods.

\section{Extracellular Protease Activity}
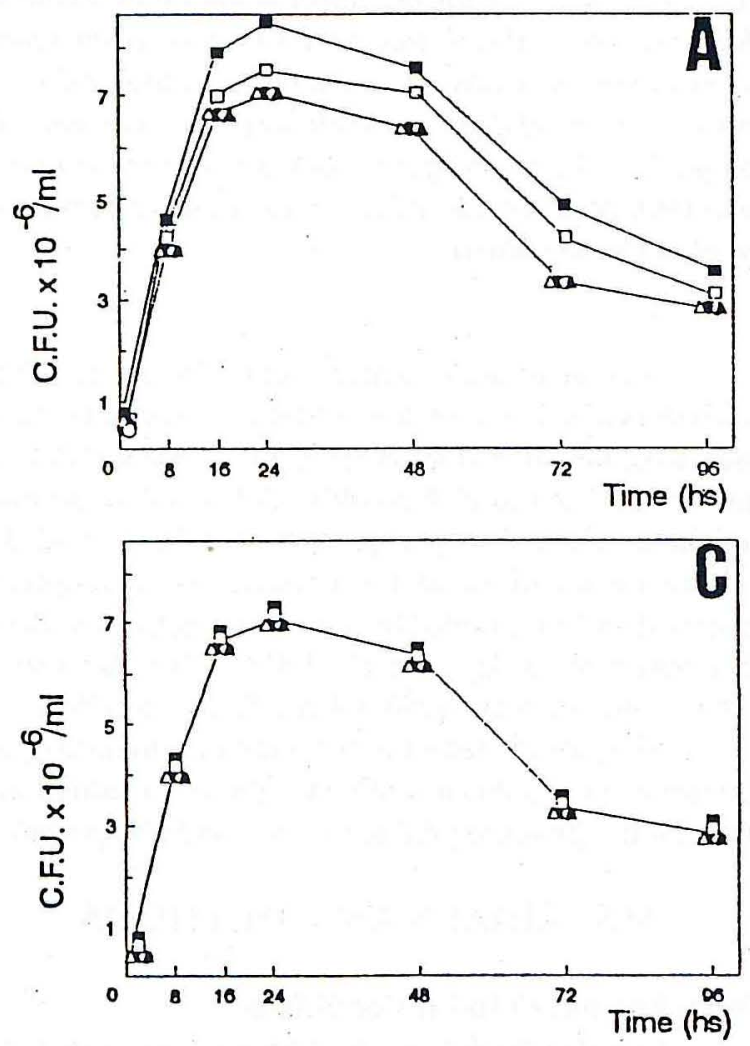

Samples of $3 \mathrm{ml}$ of $C$. lipolytica cultures, both controlled and treated, were collected at intervals of 0 , $24,48,72$ and $96 \mathrm{~h}$ of growth, and centrifugated at 2000 $\mathrm{rpm}$ for $10 \mathrm{~min}$. The culture supernatants were tested for enzyme activity. Twenty microliters of samples were loaded in $2 \mathrm{~mm}$ diameter well in YMA-Gellatin plates. The plates were incubated for $24 \mathrm{~h}$ at $27^{\circ} \mathrm{C}$. After this period, the precipitation zonearound wells were measured. The plates were prepared in triplicate.

\section{Cellular Protease Activity}

Samples of $0,1 \mathrm{ml}$ of controlled and treated cultures, collected at intervals of $0,24,48,72$ and $96 \mathrm{~h}$ of culture, were diluted in PBS buffer $\mathrm{pH} 7,0$ and plated on YMAGellatin plates. The plates prepared in triplicate were incubated at $27^{\circ} \mathrm{C}$ for $24 \mathrm{~h}$, after which the precipitation zone was measured.

\section{RESULTS}

The growth of Candida lipolytica treated cultures as determined by viable cell counts was influenced by Tween 80 according to its concentration and addition time (Figure 1). Cultures treated with Tween 80 at 0 time
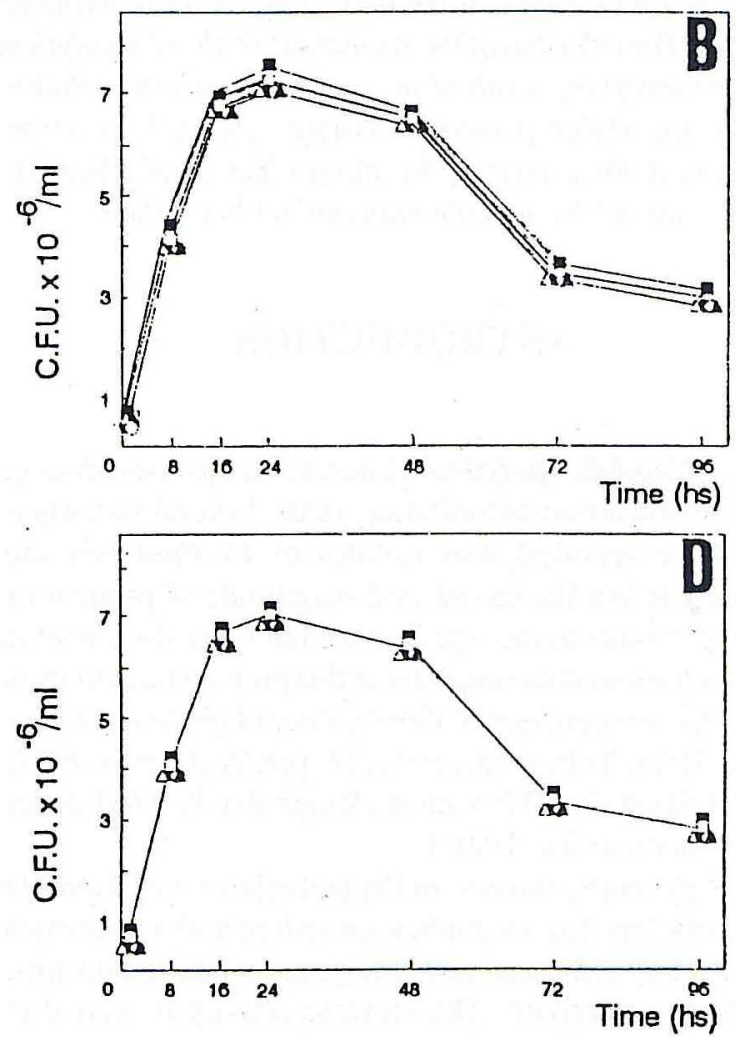

Figure 1. Cell viability of Candida lipolytica cultures treated with $0.01 \% \triangle), 0,05 \%(\triangle), 0,2 \%(0), 0,5 \%(\square)$

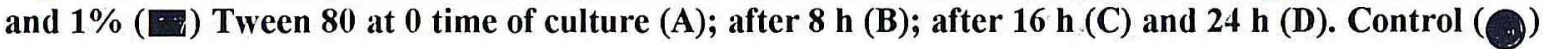


showed the highest increase in cell viability as compared to control and to other treatments and the maximum stimulation was obtained with $1 \%$ (Figure 1A). Cultures treated after $8 \mathrm{~h}$ showed a cellular viability lower than previous treatment but, higher than controlled and cultures treated after 16 and $24 \mathrm{~h}$ culture. Again, the maximum stimulation was obtaincd with $1 \%$ Tween 80 (Figure IB). cultures treated after $16 \mathrm{~h}$ and $2+\mathrm{h}$ did not show a significant difference in cell viability as compared to control culture (Figures IC and ID, respectively).

The extracellular protease activity was detected in all culture supernatant tested (Table 1). The Tween 80 concentration and addition time show influence on the enzyme activity. The highest protease activity was detected in cultures treated at 0 time of growth and the maximum activity was detected by using $1 \%$ Tween 80 . According to other $8 \mathrm{~h}$ (beginning of exponential growth phase) showed a reduction of enzyme activity as compared to previous treatment but, the protease activity was higher than cultures treated after 16 and $24 \mathrm{~h}$ and control. Culture treatments after 16 and $24 \mathrm{~h}$ did not show significant difference in protease activity as compared to control. The highest protease production was detected in samples collected after a $48 \mathrm{~h}$ culture in all supernatants tested.

The cellular protease activity assayed showed that all culture samples had positive enzyme activity which could be related to cell viability and was according to all Tween 80 concentrations and addition time.

\section{DISCUSSION}

These cxperiments show that Candida lipolytica IA 1055 , exhibit protease activity, which is influenced by Tween 80 concentrations and addition time. These results are confirmed by other authors, who showed that surfactants of Tween serics have a beneficcial effect in

Table 1 - Extracellular protease activity detected by halo formation ( $\mathrm{mm}$ ) in supernatants cultures of Candida lipolytica

\begin{tabular}{|c|c|c|c|c|c|c|c|c|c|c|c|c|c|c|c|c|c|c|c|c|c|}
\hline \multirow[b]{3}{*}{$\begin{array}{c}\text { Samples } \\
\text { (h) }\end{array}$} & \multicolumn{21}{|c|}{ Tween 80 addition } \\
\hline & \multicolumn{6}{|c|}{0} & \multicolumn{5}{|c|}{8} & \multicolumn{5}{|c|}{16} & \multicolumn{5}{|c|}{24} \\
\hline & Control & 1 & 2 & 3 & 4 & 5 & 1 & 2 & 3 & 4 & 5 & 1 & 2 & 3 & 4 & 5 & 1 & 2 & 3 & 4 & 5 \\
\hline 0 & 0 & 0 & 0 & 0 & 0 & 0 & 0 & 0 & 0 & 0 & 0 & 0 & 0 & 0 & 0 & 0 & 0 & 0 & 0 & 0 & 0 \\
\hline 24 & 11,0 & 13,0 & 11,9 & 11,6 & 11,4 & 11.0 & 12.0 & 11.8 & 11.5 & 11.2 & 11.0 & 11.8 & 11.3 & 11.0 & 11.0 & 11.0 & 11.3 & 11.1 & 11.1 & 11.0 & 11.0 \\
\hline 48 & 13,0 & 14,5 & 13,5 & 13,4 & 13,2 & 13,0 & 14,0 & 13,6 & 13,5 & 13,0 & 13,0 & 13,2 & 13,1 & 13,0 & 13,0 & 13,0 & 13,0 & 13,0 & 13,0 & 13,0 & 13,0 \\
\hline 72 & 9,5 & 11,0 & 10,0 & 9,7 & 9.5 & 9,5 & 10,5 & 10,0 & 9,6 & 9,5 & 9,5 & 9,7 & 9,6 & 9,5 & 9,5 & 9,5 & 9,7 & 9,5 & 9,5 & 9,5 & 9,5 \\
\hline 96 & 7.0 & 9,0 & 8,0 & 7,7 & 7,5 & 7,0 & 7,5 & 7,3 & 7,0 & 7,0 & 7,0 & 7,6 & 7,4 & 7,1 & 7,0 & 7,0 & 7,3 & 7,1 & 7,0 & 7,0 & 6,9 \\
\hline
\end{tabular}

Tween 80 concentrations: $1-1 \% ; 2-0,5 \% ; 3-0,2 \% ; 4-0,05 \% ; 5-0,01 \%$.

increasing the yiclds of several extracellular enzymes when included in culture medium (Reese \& Maguire, 1969; Jagger et al., 1985; Asther \& Corricu, 1987; Long \& Knapp, 1991). The authors suggest that surfactant cffect is on cell membrane permcability, but the basis for it effectiveness is not clear.

Tween 20 and Tween 80 (lauric Acid and Oleic Acid, respectively) probably' can supply fatty acids to the microorganisms cultures growth and could facilitates the uptake of nutrients into cells with the consequent stimulation to growth (Marvin, 1959; Massuco et al., 1981: Jagger et al., 1985). However, the study of Tween 80 different concentrations influence on growth and protease production by Candida lipolytica have not previously been reported.

The results showed that Tween 80 addition time and concentrations in culture medium influenced the enzyme production and growth of Candida lipolytica. Reese \& Maguire (1969), demonstrated tha 0,01\% Tween 80 added to culture medium gives the maximum stimulation of enzyme production when included at 0 time of incubation. These results are according to our experiments but, $1 \%$ Tween 80 was necessary for maximum enzyme and growth stimulation in C. lipolytica and later addition $(8 \mathrm{~h})$ still useful. This work showed that Tween 80 influence is according to its concentation and growth phase of the microorganisms.

It secms reasobable to suggest that this surfactant increase protease production by $C$. lipolytica and by other 
microorganisms simply by increasing the extent of growth. It is necessary to verify if the enzyme activity in this specie could be related to infective power.

\section{ACKNOWLEDGEMENTS:}

The authors are grateful to CNPQ, FINEP and PADCT, for the financial support, and to Dr. P.P. Andrade for the suggestions.

\section{REFERENCES}

Ahearn, D. G.; Meyers, S. P.; Nichols, R. A. (1968) Extracellular proteinases of yeast and yeastlike fungi. Applied Microbiology 16:1370-1374

Asther, M. \& Corrieu, G. (1987) Effect to tween 80 and olei acid on ligninase production by Phanerochaete chrysosporium INA/12 Enzyme Microbiology and Technology 9:245-249

Chakrabarti, A.;Nayak, N.; Talwar, P. (1991) In vitro proteinase production by Candida species. Mycopathologia 114:163-168

Cirigliano, M. C. \& Carman, G. M. (1983) A plating technique for the selective isolation of yeast utilizing water imiscible carbon. Journal of Food Science 48:1554-1555

Espinosa, E.; Sánchez, S.; Farre's, A. (1990) Nutritional factors affecting lipase production by Rhizopus delemar CDBB H313. Biotechnology Letters 12:209-214

Hankin, L.\& Anagnostakis, S. L. (1975) The use of solid media for detection of enzyme production by fungi. Mycologia 67:597-607

Helenius, A.\& Simons, K. (1975) Solubilization of membrane proteins by detergents. Biochimica et Biophysica Acta 415:29-79

Jagger, A.; Croan, S.; Kirk, K. T. (1985) Production of ligninases and degradation of lignin in agitated submerged cultures of Phenerochaete chrysosporium. Applied Environmental Microbiology 50:1274-1278

Lodder, J.\&Krieger-van Rij, N. J. W. (1984). The Yeast, a taxonomic study. Nort Holland Publ. Co., Amsterdam. 713 p.

Long, K.\& Knapp, J. S. (1991) The effect of Junlon PW 110 and tween 80 on the production of cellulotytic enzymes by Coprinus cinereus. Mycological Research 95:1077-1081
Marvin, R. M. (1959) survey of surface-active culture additives for growth of pathogenic human fungi. Mycologia, 51: 61-68

Massuco, A. E.; Mazza, L. A.; Balatti, A. P. (1981) Estudios sobre producción de proteasa alcalina. Revista Latino Americana de Microbiologia, 23: $145-149$

Meyers, S. P.\& Ahearn, D.J.(1977) Extracellular proteolysis by Candida lipoljtica. Mycologia, 69: 646-651

Ogrydziak, D. M.; Demain, A. L.; Tannenbaum, S. R. (1977)Regulation of extracellular protease production by Candida lipolytica. Biochimica et Biophysica Acta, 497: 525-538

Okeke, C. N.\& Okolo, B. N. (1990) the effect of cultural conditions on the production of lipase by Acremonium strictum. Biotechnology Letters, 12: $747-750$

Reese, E. T.\& Maguire, A. (1969) Surfactants as stimulants of enzyme production by microorganisms. Applied Microbiology, 17: 242-245

Tanford, C.\& Reynolds, J. (1974) Molecular characterization of proteins in detergent solutions. Biochemistry, 13: 2369-2376

Tobe, S.; Takimi, T.; Ikeda, S.; Mitsuzi, K. (1976) Production and some enzymatic proteties of alkaline proteinase of Candida lipolytica. Agricultural and Biological Chemistry, 40: 1087-1092

Yamada, T.\& Ogrydziak, D. M. (1983) Extracellular acid proteases produced by Saccharomy'copsis lipolytica. Jounal of Bacteriology, 154: 2331 